\title{
Effect of integrated plant nutrient management on growth, yield and leaf nutrient status of broadleaf mustard (Brassica juncea var. rugosa)
}

\begin{abstract}
Inappropriate agriculture operation with dependent on mostly chemical fertilizers has led to acidification and dropping fertility status which directly affects crop productivity. The simplest method to recover these debase land is to amend with integrated nutrient management practices thereby improving the nutrient cycle. We experimented to study the effect of integrated plant nutrient management on yield and leaf nutrient status of broadleaf mustard on farmers' field of Kathmandu Valley from August 2017 to December 2017. The experiment was laid out in Randomized Complete Block Design. There was 9 treatment viz. T1 $(1 / 2 \mathrm{NPK}+4$ ton/ha Vermicompost), T2 (3/4NPK +2 ton/ha vermicompost), T3 (1/2 NPK+ 12 ton/ha FYM), T4( $3 / 4$ NPK + 6ton/ha FYM $),$ T5 ( 1 1 $/ 2$ NPK +2 ton/ha Poultry Manure), T6 ( $3 / 4 \mathrm{NPK}+1$ ton/ha Poultry Manure), T7 (1/2 NPK +6 ton/ha Compost), T8( $3 / 4 \mathrm{NPK}+3$ ton/ ha Compost) and T9 (Control) with three replication. All the treatments were applied at the time of transplantation as basal application. In the study maximum plant height and leaves size observed in $\mathrm{T} 5(1 / 2 \mathrm{NPK}+2$ ton/ha PM$)$ and yield per plot and yield per ha was observed in T6 (3/4NPK + 1 ton/ha PM). Similarly, the maximum plant canopy volume was observed in T2 (3/4 NPK +2 ton/ha VC). The highest leaf Nitrogen, Phosphorous, and potash were found in the treatment T7 (1/2 NPK +6 ton/ha Compost), T5 (1/2 NPK +2 ton/ha Poultry Manure) and $\mathrm{T} 2(3 / 4 \mathrm{NPK}+2$ ton/ha $\mathrm{VC})$ respectively.
\end{abstract}

Keywords: broad leaf mustard, integrated nutrient management (inm), plant nutrition, poultry manure, vermicompost
Volume 4 Issue 3 - 2020

\author{
Chakra Devkota,' Bishnu Prasad Bhattarai, ${ }^{2}$ \\ Saroj Raj Mishra,' Prabin Ghimire,' Dipendra \\ Chaudhari ${ }^{3}$ \\ 'Institute of Agriculture and Animal Science, Tribhuvan \\ University, Nepal \\ ${ }^{2}$ Himalayan College of Agricultural Science and Technology, \\ Purbanchal University, Nepal \\ ${ }^{3}$ Agriculture and Forestry University, Nepal
}

Correspondence: Chakra Devkota, Institute of Agriculture and Animal Science, Tribhuvan University, Nepal, Email devkota.chakra00@gmail.com

Received: May 17, 2020 | Published: June 08, 2020

\section{Introduction}

Broad Leaf Mustard is one of the most important, popular, and traditional vegetable crops with a high degree of diversity. ${ }^{1}$ It is a highly praised winter season leafy vegetable, widely grown for its particular taste. A large Broad Leaf Mustard diversity exists in Nepal especially across the mid-hills, since the inception of vegetable research in the country, collection, evaluation, and recommendation of these local landraces of BLM have been made and have identified superior landraces, which were released for general production., ${ }^{2,3}$

Horticultural crops, mainly vegetable and leafy crops, management practices include the heavy application of chemical fertilizers which become inevitable due to the depletion of soil organic matter. The extensive use of chemical fertilizers in these crops deteriorated soil health that in turn affected productivity. ${ }^{4}$ To revitalize soil health and to enhance productivity, it is inexorable to enrich the soil using organic matter. The inclusion of organic manures with chemical fertilizers has directly influenced plant growth, yield, and nutritional values. ${ }^{5}$

Therefore, an INMS is the most efficient and practical way to mobilize all the available, accessible, and affordable plant nutrient sources to optimize the productivity of the crops/cropping systems and economic return to the farmer. Thus the main aim of this research is to provide the authentic result for farmers and students for the adoption of IPNM to improve crop productivity and nutritional values while maintaining soil health.

\section{Material and methodology}

\section{Description on experimental site}

Experimentation was carried out in the Kathmandu district of Nepal which is located on elevation 1423 meter above sea level from August 2017 to December 2017 at farmer field. The texture of the soil is Sandy loam determined by hydrometer ${ }^{6}$ with a $\mathrm{pH}$ of 6.5 having soil organic carbon content about $1.56 \%$ determined by Walkley and Black method. The average annual rainfall of the study site was $1505 \mathrm{~mm}$ and temperature of $18.1^{\circ} \mathrm{C}$.

A total of 27 plot was made with individual dimension $2.5 \times 2$ sq. meters in Random Completely Block Design having 3 Replication and 9 treatment (Table 1). Variety namely "Marpha" was used. Here doses of manures were calculated based on nitrogen percentage in various manures. There is a variation in the doses due to the different chemical composition of NPK in all types of manures. Recommended fertilizer doses was (NPK: 120:80:60 kg/ha), Urea, DAP, MOP was applied as source of NPK respectively. Manures were applied at the time of transplanting all as a basal dose. The required amounts of manures were weighted using weighing balance separately and all the manures were applied at the time of field preparation and then mixed with soil properly before seed sowing. On laboratory testing FYM contain $0.5 \% \mathrm{~N}$, vermicompost contains $1.5 \% \mathrm{~N}$, poultry manure contains $3 \% \mathrm{~N}$, and compost contain $1 \% \mathrm{~N}$ (Table 1). 
Table I Treatment details

\begin{tabular}{|c|c|}
\hline Treatments & Fertilizer applied \\
\hline TI & (I/2 NPK + 4 ton/ha Vermicompost) \\
\hline T2 & ( $3 / 4 \mathrm{NPK}+2$ ton/ ha vermicompost $)$ \\
\hline T3 & $(\mathrm{I} / 2 \mathrm{NPK}+12$ ton/ha FYM) \\
\hline T4 & (3/4 NPK+ 6 ton/ha FYM) \\
\hline T5 & $(\mathrm{I} / 2 \mathrm{NPK}+2$ ton/ha Poultry Manure) \\
\hline T6 & $(3 / 4 \mathrm{NPK}+I$ ton/ha Poultry Manure) \\
\hline T7 & (I/2 NPK+ 6 ton/ha Compost) \\
\hline T8 & (3/4 NPK +3ton/ha Compost) \\
\hline T9 & Control \\
\hline
\end{tabular}

\section{Determination of leaf nutrient status}

The samples were washed by tap water followed by $0.1 \mathrm{~N} \mathrm{HCl}$, distilled water followed by double distilled water. Then dried in the oven at $68{ }^{\circ} \mathrm{C}$. The samples were sequentially ground by electrical grinder for further analysis.

The digestion of the samples for the estimation of nitrogen was carried out in concentrated sulphuricacid by adding a digestion mixture. Total Nitrogen present in leaves was determined by the Kjeldahl method. ${ }^{7}$ The result was expressed in percentage on a dry weight basis. For the estimation of leaf P, K, digestion was done in diacid mixture prepared by mixing nitric acid and perchloric acid (AR grade) in the ration of 4:1. Total Phosphorous of Leaf content was determined by using the Vanado molybdophosphoric yellow color method. ${ }^{7}$ Total Potassium was determined by flame photometer, and the result was expressed in percentage on a dry weight basis as described by Motsara and Roy. ${ }^{8}$

\section{Crop management}

Seeding was transplanted in a plant to plant distance is $30 \mathrm{~cm}$ and row to row distance is $45 \mathrm{~cm}$ so there were 30 plants per plot. Irrigation and Weeding were done as a necessity. Harvesting of BLM was done on 55 Days after Transplanting (DAT) when all the leaves were ready as a marketable product.

\section{Observation and statistical analysis}

During the production of broadleaf mustard, all the observations were made regarding several growth parameters like height, no. of leaf per plant, leaf size, and plant canopy. Analysis of leaf nutrient i.e. available leaf nitrogen, available leaf phosphorous, leaf potash was done and Data were systematically arranged based on various observed parameters. Micro-soft Excel and Genstat (developed by VSN International Ltd) were used for the analysis of variance and other data analyses. The treatments were tested at a 5 percent level of significance.

\section{Result \& discussion}

\section{Plant height}

Maximum percentage increase in plant height as compared to T9 (Control) was observed in T5 (33.86\%) followed by T6 (29.72\%). The best result for plant height was obtained in the combination with $(1 / 2$ $\mathrm{NPK}+2$ ton/ha) poultry manure.
The positive effect of chicken manure on growth parameters obtained in this study was supported by the results of Mohammed, who stated that the addition of manure significantly increased plant height. Similarly, Eltilib et al. ${ }^{10}$ reported that chicken manure application significantly increased plant height and number of leaves of okra compared to the control (Figure 1).

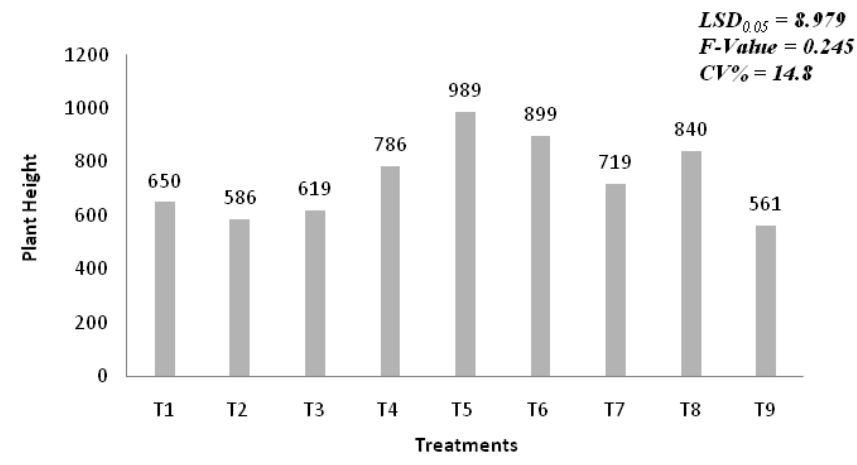

Figure I The effect of various treatments on the plant height of broadleaf mustard.

\section{Leaf size}

Highest mean value concerning leaves size of BLM was $989 \mathrm{~cm} 2$ in the treatment T5 $(1 / 2 \mathrm{NPK}+2$ ton/ha Poultry Manure $)$ which is (76.29\%) higher than the control. The minimum value was found to be $561 \mathrm{~cm} 2$ in control (T9). The higher value recorded in $1 / 2 \mathrm{NPK}+2$ ton/ha PM could be attributed to a higher level of nutrient especially Nitrogen and Phosphorous available in PM for plant growth and their release as well as synchronization of nutrients released within the short growth period of BLM. Ghanbarian et al. ${ }^{11}$ reported that PM contains higher Nitrogen and Phosphorous as compared to other manure.

The increase in leaf size observed with PM compared to the other integration or mixture of NPK with other fertilizer may be mainly due to reasons of more availability and release of nutrients by poultry manure through the growing period of BLM.. Positive effects of poultry manure on the growth have been also reported by MC Robic, ${ }^{12}$ and Adediran et al. ${ }^{13}$ (Figure 2).

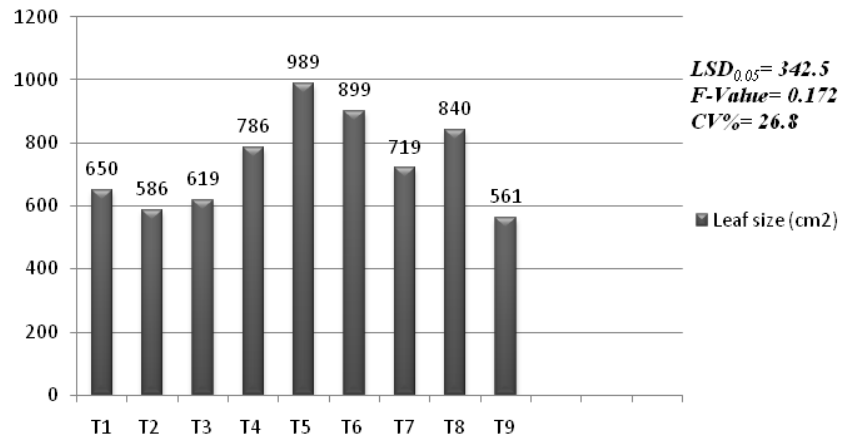

Figure 2 The effect of various treatments on the leaf size of broadleaf mustard.

\section{Plant canopy volume}

The maximum mean value regarding canopy of Broad Leaf Mustard was observed $0.0640 \mathrm{~m} 3$ in the treatment T2 $(3 / 4 \mathrm{NPK}+2$ ton/ ha vermicompost) which is $89.91 \%$ higher than control. The result showed that the application of 75 percent recommended doses of NPK with vermicompost ( 2 ton/ha) is better growth concerning plant canopy. 
Because Vermicomposts originating from the earthworm, animal manure, sewage sludges or paper-mill sludges have been reported to contain large amounts of humic substances which have a positive effect on growth. ${ }^{14-16}$ Studies of the effects of humic substances on plant growth, under conditions of adequate mineral nutrition, have consistently produced positive growth effects ${ }^{17}$ (Table 2).

Table 2 Effect of IPNM on plant canopy volume and leaf size of broad leaf mustard

\begin{tabular}{ll}
\hline Treatment & Plant canopy volume (m3) \\
\hline TI(I/2 NPK + 4 ton/ha Vermicompost) & 0.0403 \\
T2 (3/4 NPK + 2 ton/ ha vermicompost) & 0.0640 \\
T3 (I/2 NPK + I 2 ton/ha FYM) & 0.0390 \\
T4 (3/4 NPK+ 6 ton/ha FYM) & 0.0353 \\
T5 (I/2 NPK+ 2 ton/ha Poultry Manure) & 0.0543 \\
T6 (3/4 NPK + I ton/ha Poultry Manure) & 0.0477 \\
T7(I/2 NPK+ 6 ton/ha Compost) & 0.0417 \\
T8(3/4 NPK +3ton/ha Compost) & 0.0607 \\
T9(Control) & 0.0337 \\
LSD (0.05) & 0.02768 \\
F & 0.257 \\
CV\% & 34.5 \\
\hline
\end{tabular}

\section{Yield parameter}

The maximum yield per plot was obtained by the application of T6 $(3 / 4 \mathrm{NPK}+1$ ton/ha poultry manure) i.e. $4.18 \mathrm{~kg} / \mathrm{plot}$, which is $27.05 \%$ higher compared to control, followed by T8 $(3 / 4 \mathrm{NPK}+3$ ton/ ha compost) I .e. $4.01 \mathrm{~kg} / \mathrm{plot}$, which is $22.6 \%$ higher than control. The minimum yield per plant was recorded in T3 $\left(1 \frac{1}{2} \mathrm{NPK}+12\right.$ ton/ha FYM) treatment with a value of $2.98 \mathrm{~kg} /$ plot.

\section{Effect of IPNM on leaf nutrient status of BLM (Table 4)}

Table 4 Effect of IPNM on leaf nutrient status of BLM

\begin{tabular}{llll}
\hline Treatments & Nitrogen content (\%) & Phosphorous content (\%) & Potassium content (\%) \\
\hline TI(I/2 NPK + 4 ton/ha Vermicompost) & 2.1 I & 0.722 & 3.33 \\
T2 (3/4 NPK + 2 ton/ ha vermicompost) & 0.85 & 0.665 & 3.35 \\
T3 (I/2 NPK + I 2 ton/ha FYM) & 0.83 & 0.945 & 3.2 \\
T4 (3/4 NPK+ 6 ton/ha FYM) & 1.33 & 1.165 & 3.16 \\
T5 (I/2 NPK+ 2 ton/ha Poultry Manure) & 2.31 & 1.165 & 3.01 \\
T6 (3/4 NPK + I ton/ha Poultry Manure) & 0.67 & 0.665 & 2.8 \\
T7(I/2 NPK+ 6 ton/ha Compost) & 2.53 & 0.775 & 2.68 \\
T8(3/4 NPK +3ton/ha Compost) & 0.74 & 0.442 & 3.05 \\
T9(Control) & 1.08 & 1.625 & 2.83 \\
LSD (0.05) & 1.3 & 0.749 & 1.144 \\
F & 0.035 & 0.102 & 0.912 \\
CV\% & 54.3 & 47.7 & 21.7 \\
\hline
\end{tabular}

The maximum yield per ha was obtained by the treatment application of T6 $(3 / 4 \mathrm{NPK}+1$ ton/ha poultry manure i.e. 10.4 ton/ha while the minimum yield 7.4 ton/ha was recorded in the treatment $\mathrm{T} 3$ $(1 / 2 \mathrm{NPK}+12$ ton/ha FYM) (Table 3).

Table 3 Effect of IPNM on the yield of broadleaf mustard

\begin{tabular}{|c|c|c|}
\hline Treatments & $\begin{array}{l}\text { Leaf yield per } \\
\text { plot }(\mathrm{Kg})\end{array}$ & $\begin{array}{l}\text { Leaf yield per } \\
\text { ha }(\mathrm{Kg})\end{array}$ \\
\hline $\begin{array}{l}\mathrm{TI}(\mathrm{I} / 2 \mathrm{NPK}+4 \text { ton } / \mathrm{ha} \\
\text { Vermicompost })\end{array}$ & 3.47 & 8675 \\
\hline $\begin{array}{l}\text { T2 (3/4 NPK + } 2 \text { ton/ ha } \\
\text { vermicompost) }\end{array}$ & 3.65 & 9123 \\
\hline $\begin{array}{l}\text { T3 (I/2 NPK + } 12 \text { ton/ha } \\
\text { FYM) }\end{array}$ & 2.98 & 7440 \\
\hline $\begin{array}{l}\text { T4 (3/4 NPK+ } 6 \text { ton/ha } \\
\text { FYM) }\end{array}$ & 3.12 & 7793 \\
\hline $\begin{array}{l}\text { T5 (I/2 NPK+ } 2 \text { ton/ha } \\
\text { Poultry Manure) }\end{array}$ & 3.81 & 9527 \\
\hline $\begin{array}{l}\text { T6 (3/4 NPK + I ton/ha } \\
\text { Poultry Manure) }\end{array}$ & 4.18 & 10448 \\
\hline $\begin{array}{l}\mathrm{T7}(\mathrm{I} / 2 \mathrm{NPK}+6 \text { ton } / \mathrm{ha} \\
\text { Compost) }\end{array}$ & 3.45 & 8623 \\
\hline $\begin{array}{l}\text { T8(3/4 NPK +3ton/ha } \\
\text { Compost) }\end{array}$ & 4.01 & 10030 \\
\hline T9(Control) & 3.29 & 8230 \\
\hline LSD $(0.05)$ & 1.712 & 4283.7 \\
\hline $\mathrm{F}$ & 0.844 & 0.844 \\
\hline CV\% & 27.9 & 27.9 \\
\hline
\end{tabular}




\section{Available nitrogen (N)}

The maximum percent of leaf nitrogen was found in T7 $(1 / 2 \mathrm{NPK}+$ 6 ton/ha Compost) (2.53\%) compared with control followed by T5 $(2.31 \%)$ and least nitrogen content in leaf was found in T6 $(0.67 \%)$.

The nitrogen content is maximum in $\mathrm{T} 7$ because Compost can stimulate plant growth, root development, and thus nutrient uptake, Walker and Bernal. ${ }^{18}$ This result is similar to the result obtained by Nevens and Reheul, ${ }^{19}$ their study showed that in Silage maize N uptake and $\mathrm{N}$ concentration in maize were higher when compost was applied. However, the availability of $\mathrm{N}$ in compost is low, but the available nitrogen in T7 (50\% NPK and 50\% compost) is observed highest. This is maybe because of supplementary $\mathrm{N}$ in the form of inorganic fertilizer together with compost has enhanced $\mathrm{N}$ availability to crops.

\section{Available phosphorous (P)}

The maximum percentage of phosphorous content was found in T5 $(1.165 \%)$ followed by T4 $(1.165 \%)$ and minimum phosphorous content in leaf was found in T8 $(0.422)$.

These findings showed that the application of $1 / 2 \mathrm{NPK}+2$ ton/ha $\mathrm{PM}$ retained high phosphorous content in a leaf because of enzymatic activities of microbial organisms in PM. PM and NPK increased leaf $\mathrm{N}, \mathrm{P}, \mathrm{K} \mathrm{Ca}$, and $\mathrm{Mg}$ content of pumpkin, leaf nutrient content tended to increase with the level of poultry manure. ${ }^{20}$

\section{Available potassium (K)}

The maximum percentage of potassium content was found in T2 $(3 / 4 \mathrm{NPK}+2$ ton/ha VC) $3.35 \%$ followed by T1 $(3.33 \%)$ and the least potassium content was found in T6 $(2.80 \%)$.

These findings show that the application of $3 / 4 \mathrm{NPK}+\mathrm{VC}$ retained high potassium content in leaf this is because VC can supply both macro and micronutrients in the soil for optimum plant growth. ${ }^{21}$

\section{Conclusion}

At It is concluded that combine use of $1 / 2 \mathrm{NPK}+2$ ton/ha Poultry Manure was more efficient for plant growth, leaf size and yield of broad leaf mustard. The maximum available leaf nitrogen $(2.53 \%)$ was observed in $1 / 2 \mathrm{NPK}+6$ ton/ha Compost $\left(\mathrm{T}_{7}\right)$, available phosphorous $(1.165 \%)$ with $1 / 2 \mathrm{NPK}+2$ ton/ha poultry manure $\left(\mathrm{T}_{5}\right)$ and available potassium $(3.35 \%)$ was found to be maximum with the application of $3 / 4 \mathrm{NPK}+2$ ton/ha vermicompost $\left(\mathrm{T}_{1}\right)$, respectively. Integrated plant nutrient management is best approach for sustainable soil and crop management in present context. It reduces the cost for farmers on chemical fertilizers and maintains soil fertility on long run.

\section{Acknowledgments}

None.

\section{Conflicts of interest}

Authors declare no conflict of interest exists.

\section{References}

1. Pandey IR. Status of vegetable genetic resources in Nepal. 1995:112-118.

2. Pradhanang PM, SR Ghimire, SR Pandey, Report on studies of TMV of BLM, LARC working paper No 93/10. LARC, Kaski Nepal. 1993.
3. Panthee DR. Dormancy behavior of radish, B. L.M, cauliflower, and cress seeds. Lumle Agriculture Research Center, Kaski, Nepal. 1998.

4. Dipendra Chaudhari, Shree Prasad Vista, Prabin Ghimire, et al. Influence of agricultural lime in alleviating acidity level of various acid soils. World J Agri \& Soil. 2019;3(3).

5. Mukherjee DS, Mitra AC. Effect of oil cake on change in carbon and microbial population in soil. Journal of Indian Society of Soil Science. (1991);39:457-194.

6. Bouyoucos GJ. Hydrometer method improved for making particle size analyses of soils. Agron J. 1962;54:464-465.

7. Jackson ML. Soil chemical analysis. Asia publishing House Bombay. $1975 ; 10-205$.

8. Motsara MR, Roy RN Guide to laboratory establishment for plant nutrient analysis. Food and Agriculture Organization of the United Nations FAO fertilizer and plant nutrition bulletin No. 2008 .

9. Mohammed MA. Effect of farm yard manure on soil fertility, microbial activity, and wheat grain yield. M.Sc. Thesis, University of Gezira, WadMedani, Sudan. 1993.

10. Eltilib AM, Ali AM, Abdelallah MA. Effect of chicken manure and salinity on growth and leaf nitrogen phosphorous and potassium contents on okra grown in two soil types. University of Khartoum Journal of Agric. Sc. 1994;1(2):16-36.

11. Ghanbarian D, Youneji S, Fallah S, et al. Effect of broiler litter on physical properties, growth, and yield of two cultivars of cantaloupe (Cucumismelo). Int J AgrBiol. 2008;6:1814-9596.

12. McRobie G. Tools for organic farming: a manual of appropriate equipment and treatments. Intermediate Technology Publications Ltd. 1990.

13. Adediran JA, Taiwo LB, Akande MO, et al. Comparative effects of organic-based fertilizer and mineral fertilizer on the dry matter yield of maize. Boise Research Communication. 1999.

14. Albanell E, Plaixats J, Cabrero T. Chemical changes during vermicomposting (Eiseniafetida) of sheep manure mixed with cotton industrial wastes. Biology and fertility of soils. 1988;6(3):266-269.

15. Petrussi F, De Nobili M, Viotto M, et al. Characterization of organic matter from animal manures after digestion by earthworms. Plant and Soil. 1988;105(1):41-46.

16. Garcia C, Ceccanti B, Masciandaro G, et al. Phosphatase and $\beta$-glucosidase activities in humic substances from animal wastes. Bioresource Technology. 1995;53(1):79-87.

17. Chen Y, Aviad T. Effects of humic substances on plant growth 1. Humic substances in soil and crop sciences: Selected readings, (humic substances). 1990;161-186.

18. Walker DJ, Bernal MP. The effect of olive mill waste compost and poultry manure on the availability and plant uptake of nutrients in a highly saline soil. Bioresearch Technology. 2008;99(2);396-403.

19. Nevens F, Reheul D. The application of vegetable, fruit, and garden waste (VFG) compost in addition to cattle slurry in a silage maize monoculture: nitrogen availability and use. European Journal of Agronomy. 2003;19(2):189-203.

20. Awodun MA. Effect of poultry manure on the growth, yield and nutrient content of fluted pumpkin (Telfariaoccidentalis Hook F). Asian J Agric Res. 2007;1:67-73.

21. Harris GD, Platt WL, Price BC. Vermicomposting in a rural community, Biocycle. 1990. 